\title{
整
}

\section{'n Ondersoek na godsdiens-inklusivisme en godsdienspluralisme by M.A. Kruger}

\author{
D.G. Breed
}

Navorser: Skool vir Bybelwetenskappe

Fakulteit Teologie

Potchefstroomse Universiteit vir $\mathrm{CHO}$

POTCHEFSTROOM

E-pos: dbreed@stocks.co.za

\begin{abstract}
An investigation into religious inclusivism and religious pluralism in the work of M.A. Kruger

In his exegesis of Romans M.A. Kruger arrives at the conclusion that there can be people who do not know the Scriptures or have not heard the contents of Scripture but still have true faith. Kruger's conclusion indicates similarities with several writers who reject the religious-exclusive view that only those who know Jesus Christ and believe in Him are saved. This article explores the question to what extent Kruger's views correspond with two ways of theological thought, that is, religious inclusivism and religious pluralism.
\end{abstract}

\section{Opsomming}

'n Ondersoek na godsdiens-inklusivisme en godsdienspluralisme by M.A. Kruger

M.A. Kruger kom in sy eksegese van Romeine 1 tot 4 tot die gevolgtrekking dat daar onder dié mense wat die Skrif of die prediking van die Skrif nie ken nie, individue kan wees wat tog die ware geloof het. Kruger se gevolgtrekking toon ooreenkomste met verskeie skrywers wat die godsdiens-eksklusiewe standpunt verwerp dat alleen hulle wat Jesus Christus ken en in Hom glo, gered is. In hierdie artikel word ondersoek in watter mate Kruger se standpunte ooreenkom met twee denkstrome in die teologie, te wete godsdiens-inklusivisme en godsdienspluralisme.

\section{1. 'n Nuwe perspektief op nie-Christelike godsdienste}

Mechiel Andries Kruger (1983:378), 'n geëmeriteerde teologiese professor van die Gereformeerde Kerke in Suid-Afrika stel "dat daar ook onder 
diegene wat buite Israel was in die ou bedeling en onder diegene wat die Skrif of die prediking van die Skrif nie het nie, mense was en kan wees wat die ware geloof het". Daar is sekere ooreenkomste tussen Kruger se standpunt en ander skrywers ${ }^{1}$ wat ernstige bedenkinge uitspreek oor die godsdiens-eksklusivistiese standpunt ${ }^{2}$ dat alleen mense wat Christus ken en persoonlik in Hom glo, gered kan word. Volgens De Klerk (1998:47) werk die Here se Gees ook in ander godsdienste en aanvaar God mense in ander godsdienste en wel op grond van die verdienste van Christus. Bosch (1991:483) pleit vir 'n opregte openheid en opsigte van ander gelowe en sê dat ons nie behoort aan te gaan met ons ou benadering teenoor ander gelowe nie. Tutu (1994:126-127) weer waarsku teen 'n vyandigheid wat weier om die geldigheid van meervoudige religieuse godsdienste" te erken en sê dat die Christendom nie alleenreg op die waarheid het nie.

Gaybba (1994:3) beweer dat daar 'n groeiende oortuiging onder teoloë is dat ander godsdienste nie hulle bestaan bloot aan die invloed van die Bose of aan menslike faktore te wyte het nie, maar aan 'n spesiale openbarende teenwoordigheid van God. Amaladoss (1986:222) praat van 'n paradigmaverskuiwing wat tans in hierdie verband plaasvind en sê: "Under the impact of a positive experience of other religions, the centre of the framework is shifting from church to the kingdom." Hierdie denkverskuiwing hou op verskeie terreine belangrike gevolge in. Amaladoss (1986:221) sê byvoorbeeld dat hierdie verandering veroorsaak dat ons op 'n nuwe manier kyk na Christus, die kerk, verlossing en sending"3. Ook D'Costa (1991:68-69), Ketshabile (1997:5) en Schroeder (1999:165-170) dui aan dat dié nuwe siening veral kerke se motivering om die evangelie te verkondig, raak.

In die hedendaagse denke oor nie-Christelike godsdienste is daar veral twee denkrigtings wat na vore tree, te wete godsdiens-inklusivisme en godsdienspluralisme (vgl. Erickson, 1996:13-142 en Shenk, 1997:34-73). In hierdie artikel word nagegaan in watter mate M.A. Kruger se standpunte deel vorm van hierdie twee denkstrome. Daar word eerstens gepoog om godsdiens-inklusivisme en -pluralisme nader te omskryf. Vervolgens word ondersoek ingestel in watter mate Kruger se siening met hierdie denkstrome ooreenkom en verskil en ten slotte word tot ' $n$

$1 \quad$ Vergelyk Anderson (1998:159-160) vir 'n bibliografie van twee en sewentig boeke wat oor hierdie onderwerp verskyn het.

2 Vergelyk Schenk (1997:34-37) vir 'n nadere beskrywing van die godsdiens-eksklusiewe standpunt.

3 Vir ander redes vir dié veranderde denke vergelyk Athyal (2002:208-209), Carson (1996:37-51) en Kauuova (1997:17-24). 
gevolgtrekking gekom. In hierdie artikel word die standpunte van Kruger nie beoordeel nie, aangesien die ander artikels wat in hierdie uitgawe van In die Skriflig verskyn, sodanige beoordeling doen.

\section{Godsdiens-inklusivisme}

Om meer duidelikheid te kry wat godsdiens-inklusivisme behels, word aandag gegee aan 'n verklaring van Vaticanum 2 van 1965 en aan die standpunte van 'n aantal skrywers waarin 'n inklusivistiese benadering na vore kom. Daarna word 'n samevatting van die inklusivistiese denkrigting gegee.

\subsection{Vaticanum 2 (1965)}

Op die tweede Vatikaanse Konsilie van 1965 het die Rooms-Katolieke Kerk 'n verklaring uitgereik wat volgens Bosch (1979:185) dui op 'n nuwe verstaan van nie-Christelike godsdienste. Dit is bekend dat die RoomsKatolieke Kerk voor 1965 Chrístene wat met die Rooms-Katolieke Kerk verskil het, selfs "ketters" en "skeurmakers" genoem het (Bosch, 1979: 184). In die inleiding van bogenoemde verklaring (Vatican II, 1981:80-86) beklemtoon die kerk die omvang van God se plan van redding vir die hele mensheid. Die verklaring stel dat mense in nie-Christelike godsdienste poog om die raaisels en probleme van die mens se bestaan op te los en erken dat sekere dinge in nie-Christelike godsdienste waar en heilig is. Volgens dié verklaring weerspieël dit wat in ander godsdienste geleer en onderhou word, dikwels "the brightness of that Truth which is the light of all men". Vaticanum II roep "her sons" om op grond van "prudence and charity" hulle te voeg by lede van ander godsdienste deur middel van samesprekings en samewerking. Hoewel dit duidelik is dat hierdie verklaring ' $n$ wysiging in standpunt verteenwoordig, blyk dit egter dat die Rooms-Katolieke Kerk nie aanvaar dat daar naas Christus ander verlossers kan wees nie. lemand in 'n nie-Christelike godsdiens sou alleen salig kon word deur Jesus Christus se verlossingswerk. Die Rooms-Katolieke Kerk sien Christus steeds as die bron van alle genade.

\subsection{Karel Rahner}

Knitter (1985:125) noem Rahner die "chief engineer" van die verklaring wat Vaticanum II uitgereik het. Volgens hom het Rahner met sy "bold explorations into unfamiliar theological territory" die weg voorberei vir die verklaring van die Rooms-Katolieke Kerk aangaande ander godsdienste. Rahner se teologie word ook beskryf as "embodying the mainline Catholic view" (Wright, 1992:217). Rahner (1981:62-63) se vertrekpunt is God se universele en ernstige reddende plan vir alle mense. Hy sê byvoorbeeld: "God desires the salvation of everyone" en beklemtoon 
tweedens dat God alleen redding skenk deur die verlossingswerk van Christus. In die lig van God se wil dat almal gered word en dat redding alleen deur Christus kom, glo Rahner dat dit nie moontlik is dat alle mense buite die invloed van die Christendom verlore sal gaan nie. God sal volgens hom sorg dat alle mense blootgestel word aan die moontlikheid van redding. Volgens Rahner bevat godsdienste buite die Christendom "supernatural elements arising out of the grace which is given to men as a gratuitous gift on account of Christ". Daar is dus binne ander godsdienste mense wat, alhoewel hulle nog nooit van Christus gehoor het nie en nie persoonlik in Hom glo nie, "anonieme Christene" is. Rahner se standpunt oor anonieme Christene in ander godsdienste beïnvloed ook sy siening van sending. Wanneer sendelinge die evangelie aan mense in ander godsdienste verkondig, werk hulle volgens Rahner (1981:60) nie met heidene nie. Die anonieme Christene in ander godsdienste word alleen gelei om beter te verstaan wat dit beteken om kinders van God te wees en word net gehelp om meer aan God toegewyd te wees.

\subsection{Hans Küng}

Küng, 'n Rooms-Katolieke teoloog, vind Rahner se standpunt oor anonieme Christene in nie-Christelike godsdienste onaanvaarbaar. Hy (Küng, 1976:98) beskou hierdie standpunt as deel van die ou dogma van die Rooms-Katolieke Kerk dat daar buite die Kerk geen redding te vinde is nie. Küng poog om langs 'n ander weg meer inklusivisties te dink. Volgens hom moet daar wegbeweeg word van 'n kerksentriese siening na 'n Godsentriese siening waarin God se plan van redding erken word. Hy glo dat God se plan vir verlossing ook ander godsdienste insluit. Küng (1967:52) aanvaar dat 'n mens gered word binne die godsdiens wat aan hom binne sy historiese situasie beskikbaar gestel word. Hy noem dit die "ordinary way of salvation". Christene wat deel is van die Christelike tradisie, word volgens Küng langs die buitengewone manier ("extraordianary way") salig. Küng beklemtoon egter die sentrale plek van Christus met betrekking tot ander godsdienste. Sonder kennis van Christus kan mense in ander godsdienste nie werklik die redding wat in hulle werksaam is, verstaan en waardeer nie. Die openbaring in ander godsdienste ontvang volle verwerkliking in Christus. Hy verduidelik dat ander godsdienste sonder Christus vasgevang is in "circular thinking, fatalism, unwordliness, pessimism, passivity, caste spirit”. Volgens Küng (1976:113) dui dit die noodsaaksaaklikheid aan waarom die evangelie aan mense in ander godsdienste verkondig moet word: "... God may not remain for them the unknown God". Die Christelike verkondiging en sending wat Jesus aankondig, is vir diesulkes nodig. 


\subsection{Clark H. Pinnock}

Pinnock tree in die tweede helfte van die twintigste eeu na vore as 'n Protestantse teoloog wat 'n sterk voorstander is van godsdiensinklusivisme. Volgens Yong (1999:329) is Pinnock een van die min "evangeliese teoloë" wat die afgelope dekade werklik sistematies besin het oor die vraag of dit moontlik is dat mense in ander godsdienste ook verlostes kan wees. Pinnock sluit in 'n groot mate aan by die verklaring van die Vaticanum II, asook by die standpunte van Rahner en Küng. Pinnock (1992:18-47) beklemtoon dat God se verlossingswerk in Jesus Christus bedoel was vir die hele wêreld. Volgens hom moet Christene wegbeweeg van 'n "fewness doctrine" na 'n "optimism of salvation". Wie meedoen aan hierdie denkverskuiwing sal volgens Pinnock (1992:46) besef dat God nie slegs 'n klein groepie mense uit die totale mensdom sal red nie. God volg nie 'n "small salvific program" nie. Pinnock hou egter daaraan vas dat saligheid alleen deur Christus verkry kan word. Naas dié mense wat deur hulle geloof in Christus saligheid ontvang, maak God volgens Pinnock (1992:157-158) die saligheid ook aan mense buite die kerk deur die "faith principle" beskikbaar. Hy sê dat mense volgens die Bybel nooit deur die inhoud van hulle teologie gered word nie, maar deur hulle geloof. Volgens Pinnock (1992:104-106) maak God Homself in die algemene openbaring sodanig bekend dat mense daarop in geloof kan reageer: "Because of cosmic or general revelation, anyone can find God anywhere at any time". Pinnock wys in hierdie verband ook op die werk van Christus en die Heilige Gees in die kosmos. Hy sê die ewige Seun van God en Logos werk nie net deur die evangelie nie, maar ook in die hele werklikheid. "The Logos connects Jesus of Nazareth to the whole world and guards the Incarnation from becoming a limiting principle." Hy noem ook die Gees 'n kosmiese krag wat nie beperk is tot "Christian movements" nie, maar wat in die totale skepping werk. Aangesien God Hom dus aan almal openbaar, insluitend aan mense in ander godsdienste, word mense geoordeel op grond van die lig wat hulle ontvang het en die wyse waarop hulle op hierdie lig reageer het. As Skriftuurlike begronding vir hierdie standpunt, verwys Pinnock (1992: 113) na Hebreërs 11:6. Pinnock verskil met Rahner oor die vraag of mense buite die Christendom "anonieme Christene" genoem kan word. ${ }^{4}$ Hy sê die feit dat mense buite die Christendom in geloof op God se openbaring reageer, "make them right with God, but it cannot make them messianic believers". Volgens Pinnock (1993:114) is dit steeds nodig dat die evangelie met ywer verkondig word. Die motivering is volgens hom nie meer die "hell-fire insurance concept of salvation" nie. Sending moet

4 Richard (1994:89-99) poog om aan te toon dat Pinnock in wese ook maar die teorie van anonieme Christene in ander godsdienste aanvaar. 
gedoen word omdat mense in ander gelowe wat reeds positief gereageer het op die lig wat hulle van God ontvang het, deur die evangelie toegang kry tot 'n voller maat van God se genade en krag in Jesus Christus. Die verkondiging van die evangelie kan ook daartoe lei dat mense in ander gelowe, wat die lig verwerp het wat voorheen tot hulle beskikking was, wel tot geloof kan kom.

\subsection{John Sanders}

Sanders, 'n dosent in Filosofie en iemand wat beskryf word as 'n "evangelical Christian", volg baie duidelik in die voetspore van Pinnock (Gillis, 1996:140). Sanders (1995:36-38) beklemtoon, soos Pinnock, dat God wil hê dat alle mense gered word en sê dat die redding wat Christus verwerf het, vir alle mense beskikbaar is. Omdat redding ook beskikbaar is vir mense wat nie die evangelie gehoor het nie, praat Sanders van die "wider hope". Volgens hom aanvaar God deur Christus alle mense. Alleen wanneer mense God verwerp, word hulle deur God verwerp. Sanders verwys ook soos Pinnock na die "faith principle" om aan te dui hoe dit moontlik is dat mense wat Christus nie ken nie, gered kan word: "Genuine faith in God contains some truth about God, whether that truth comes from the Bible or from God's creation. Faith means that a person responds in trust to the giver of the truth." Sanders beklemtoon die werk van die Heilige Gees met betrekking tot die geloof in God: "The Holy Spirit seeks to develop faith in us regardless of the sort of revelation we have." Sanders (1992:284-286) glo dat die evangelie aan mense buite die Christendom verkondig moet word. Hy voer vier redes aan waarom dit gedoen moet word:

- Jesus het aan sy volgelinge die opdrag gegee om die evangelie te verkondig.

- lemand wat die liefde van God in Christus deur die werk van die Gees ervaar het, het die behoefte om dit met ander te deel.

- Daar is in hierdie wêreld mense wat nie in God glo nie en hulle moet opgeroep word tot geloof.

- God wil dat ook dat die mense in ander gelowe die volheid van lewe wat met Pinkster aangebreek het, ervaar.

\subsection{Samevatting}

Uit die voorafgaande is dit moontlik om 'n algemene beskrywing van godsdiens-inklusivisme te gee. 
- In die godsdiens-inklusivisme word benadruk dat God Hom nie net aan sekere mense openbaar nie, maar aan almal. Hierdie openbaring is genoegsaam sodat mense tot geloof kan kom en gered kan word.

- Godsdiens-inklusiviste wys daarop dat God volgens die Bybel wil hê dat alle mense gered word. Dit is daarom onbybels om te aanvaar dat God sal toelaat dat so baie mense wat nie van Christus gehoor het nie, verlore sal gaan.

- Die universele uitwerking van Christus se verlossingswerk word in die godsdiens-inklusivisme sterk op die voorgrond geplaas.

- In godsdiens-inklusivisme word daaraan vasgehou dat daar buite Christus, geen saligheid is nie. Alleen deur die verlossing wat Christus bewerk, kan die mens met God versoen word.

- Hoewel die versoeningswerk van Christus ontologies nodig is om die saligheid te verkry, is die versoeningswerk volgens die inklusivisme nie epistomologies nodig nie. Mense kan dus salig word sonder dat hulle die Bewerker van hulle saligheid, Christus, ken. Dit sou daarom ook moontlik wees dat mense in nie-Christelike godsdienste, mense wat nie van Christus gehoor het nie, wel deur Christus verlos word.

In die inklusivisme word sending steeds as belangrik beskou. Die rede waarom sending steeds belangrik is, is nie omdat mense wat nie die evangelie gehoor het nie, almal verlore gaan nie. Sending is vir inklusiviste belangrik omdat mense in ander godsdienste wat wel gered is, eers die volheid van hulle redding sal ervaar as hulle ook die boodskap van die Skrif ken. Sending is ook belangrik omdat daar wel in ander godsdienste mense is wat God se openbaring in die skepping verwerp. Die evangelie stel die ongelowige voor 'n kragtiger openbaring as God se openbaring in die skepping.

\section{Godsdienspluralisme}

Vir baie skrywers is godsdiens-inklusivisme onaanvaarbaar en hulle volg 'n meer pluralistiese denkrigting. Om meer duidelikheid te verkry wat godsdienspluralisme behels, word 'n kort uiteensetting gegee van die standpunte van enkele skrywers wat pluralistiese denke openbaar. Ná hierdie uiteensetting word 'n kort beskrywing van godsdienspluralisme gegee.

\subsection{John Hick}

Hick, 'n lidmaat van die Presbiteriaanse Kerk in Engeland en 'n lid van die All Faiths for One Race, is een van die mees invloedryke skrywers oor godsdienstige pluralisme (Stetson, 1994:6-9; Turner, 1991:77). Hick 
beoordeel enige vorm van godsdienseksklusivisme baie negatief. Hy (Hick, 1995:19) vind dit onaanvarbaar dat God die meerderheid van die menslike geslag wat nog nooit die Christelike geloof teëgekom of aanvaar het nie, tot die ewige verdoemenis veroordeel. Hy vervolg dat hy persoonlik so 'n God sou sien as die duiwel! Volgens hom is ook die inklusivistiese standpunt van Rahner en andere bloot maar deel van die laaste dae van 'n sterwende dogma.

Hick (1973:131) staan 'n Copernikaanse rewolusie in die teologie en godsdienstige denke voor. Soos Copernicus die ou denke dat die aarde in die sentrum van die heelal was, verwerp het, vereis hierdie revolusie in die godsdiens ook 'n denkverskuiwing. Die dogma dat die Christendom die sentrum is, moet naamlik verskuif na die besef dat dit God is wat in die sentrum is en dat alle godsdienste van die mensdom, insluitend ons eie, om God wentel en aan hom diensbaar is. Hick (1987: 23-30) glo dat die Christendom nooit in 'n meerderwaardige posisie teenoor ander gelowe geplaas mag word nie. Hy stel dat daar nie gronde is "for maintaining that Christianity has produced or is producing more saints, in proportion to population, or a higher quality of saintliness, than any other of the great streams of religious life" nie. Volgens hom toon die werklikheid dat alle godsdienste in 'n sekere opsig goed is en in 'n ander opsig sleg is.

Op grond van soveel ooreenkomste tussen verskillende godsdienste lei Hick (1981:177-178) voorts af dat daar slegs een God is wat die maker van en heerser van almal is. Ook voer hy aan dat die verskillende groot wêreldgodsdienste in werklikheid daardie een God aanbid, maar op grond van verskillende, oormekaarskuiwende konsepte of verstandelike beelde van hom. Hierdie God wat volgens Hick (1995:27) die bron en grond van alles is, noem hy die "ultimate ineffable Reality". Die "Real" is "ineffable" want sy/haar natuur "is beyond the scope of our networks of human concepts". Hick (1995: 27) sê: "The Real in itself cannot properly be said to be personal or impersonal, purposive or non-purposive, good or evil, substance or process, even one or many".

In navolging van Immanuel Kant maak Hick ten opsigte van die "supernatural environment" 'n onderskeid tussen die "noumenal world" en die "phenomenal world." Wat die mens se bewustheid van God betref, onderskei hy tussen die "noumenal Real, the Real an 'sich" en "the Real as humanly perceived in different ways as a range of divine phenomena". Die verskillende godsdienste word daarom deur Hick gesien as geldige menslike reaksie op "the Real". Hick gee baie spesifiek aandag aan die uniekheid van Christus. Daar kan volgens Hick met sekerheid uit die Skrif afgelei word dat Jesus nie aan Homself gedink het as "God incarnate" nie. Die belydenis van die kerk dat Christus naas sy 
mensheid ook God is, moet volgens hom (Hick, 1974:154) gesien word as 'n verdere ontwikkeling binne die kerklike teologie. Hierdie ontwikkeling binne kerklike teologie moet op 'n sekere manier verstaan word. Dit sou volgens Hick (1981:185-186) 'n fundamentele dwaling wees om die vleeswording van Christus as 'n feitelike hipotese te hanteer. Die belydenis dat Jesus Christus ware God én ware mens is, moet gesien word as 'n "mitologiese stelling". Met die belydenis aangaande Jesus se Godheid word alleen maar die waargenome feit na vore gebring dat Hy ons "sufficient, effective and saving point" met God is. Jesus is dan vir die Christen die een deur wie ons redding gevind het. Daar is egter ruimte dat daar ook ander oorgelewerde aspekte van reddende kontak tussen God en mens kan wees. Hoewel enige meerderwaardige posisie van enige godsdiens bo 'n ander vir Hick onaanvaarbaar is, wil hy nie wegdoen met sending nie. Hy sê die evangelie is 'n universele boodskap wat bedoel is vir elkeen tot wie se hart dit spreek. Hy sê egter dat alle godsdienste die taak het om hulle boodskappe universeel bekend te maak. Sending met die oog op bekering moet egter gestaak word. Godsdienste moet liewer hulle heilige geskrifte in alle tale vertaal sodat mense akkurate kennis van die godsdienste kan verkry. Daaruit kan dan, volgens Hick, 'n gesindheid van vrede en dialoog tussen die verskillende godsdienste volg.

\subsection{Raimon Panikkar}

Panikkar is ' $n$ Rooms-Katolieke priester wat goed geskool is in die Hindoeïsme. Hy (Panikkar, 1999:103-109) is 'n voorstander van "ecumenical Ecumenism". Panikkar sê dat die pogings wat tans aangewend word om eenheid tussen Christene te bewerk sonder om die bestaande diversiteit van oortuigings te vernietig, ook uitgebrei moet word na 'n nuwe openheid vir die hele menslike geslag. Geen godsdiens kan volgens Panikkar daarop aanspraak maak dat dit die algehele en universele reeks menslike ervarings van die Heilige kan uitput nie. Vir Panikkar (1981:78-96) is die verskillende gedagtes in die onderskeie godsdienste van kardinale belang. Elke interpretasie van die grondliggende godsdienstige gegewe verryk en kwalifiseer die Misterie wat nie suiwer transendentaal of immanent is nie.

Panikkar se Christologie moet teen die agtergrond van sy beskouing van die werklikheid verstaan word. Hy het 'n "cosmotheandric vision" waarin die hele werklikheid gesien word as 'n drievoudige polariteit: kosmies, goddelik en menslik (Pannikar, 1999:24). Volgens Pannikar (1981:169) is daar nie twee werklikhede nie: nie die werklikhede van God én mens (plus die wêreld) nie, maar ook nie net één werklikheid, naamlik God óf die mens nie. God en mens is volgens hom "in close constitutive collaboration for building up of reality, the unfolding history, and the 
continuation of creation ...". Christus (of die Logos) is vir Panikkar die simbool van die eenheid tussen God, mens en wêreld. Volgens hom tree Christus op as bemiddelaar, skakel en "conveyer" tussen God en die res (mens en kosmos). Christus is die enigste priester van die kosmiese priesterdom, die Here by uitnemendheid. Christus is ook vir hom die universele simbool van redding. Panikkar beklemtoon egter dat Christus nie beperk moet word tot 'n bloot historiewe figuur van Nasaret nie. Panikkar (1999:71) sê dat Christus die enigste middelaar is, maar die Christendom het nie 'n monopolie op Hom nie. Inteendeel - Christus is teenwoordig en werksaam in enige godsdiens - watter vorm of naam dit ook al het.

Vir Panikkar (1987:93-95) is die tyd waarin Christene mense wil "missionize" verby. Die mensdom het volgens hom nou die tyd betree waarin Christene andere moet dien en by hulle leer. Christene is nou opregte deelnemers aan 'n ope dialoog. Dialoog is vir Panikkar (1999: $x i x)$ nóg ' $n$ vredestrategie nóg 'n metode om beter te verstaan. Dialoog is dit alles en ook veel meer, want ten eerste impliseer dit 'n visie van die werklikheid wat nóg monisties, nóg dualisties of atomisties is. Ek is nie die Ander nie, maar die Ander is ook nie ek nie. Ons is saam, want ons almal deel die Woord.

\subsection{Stanley J. Samartha}

Samartha is 'n ouderling van the Church of South India en was vanaf 1968 tot 1980 voorsitter van die Wêreldraad van Kerke se "Program on Dialogue with People of Living Faiths and Ideologies". Samartha (1982: 97 ) is oortuig dat die groot godsdienste van die wêreld bloot verskillende reaksies is op die "Mystery of God or the Sat or the Transcendent or Ultimate reality ...". Samartha (1982:152) sê dat God alleen as die Absolute erken moet word en dat alle godsdienste relatief is. Godsdienste verskil van mekaar omdat elkeen gevorm is binne spesifieke taalkundige, sosiale en historiese omstandighede. Vir Samartha (1982: $152-153)$ is dit egter belangrik dat hierdie relativering van godsdienste nie daartoe lei dat die absoluuthied van die Goddelike waarheid in elke godsdiens ontken word nie. Hy sê dat spesifieke godsdienstige response slegs waar kan wees in soverre hulle nadink oor of deelneem aan iets van dié waarheid en mense daarheen lei.

In die kern van elke godsdiens is daar iets wat alleenlik, onderskeidend of beslis tot daardie godsdiens behoort. Samartha (1982:72-73) beklemtoon dat die werk van die Heilige Gees nie beperk moet word tot die Joods-Christelike tradisie nie. Volgens hom dui die Skrif en die tradisie sekere tekens aan waaraan die werk van die Gees in ander godsdienste herken kan word. Hy noem orde, eenheid, vitaliteit, kreatiwiteit en 
bereidheid om mekaar se laste te dra as tekens van die werk van die Gees. In sy Christologie stel Samartha (1982:95-96) dat die NuweTestamentiese skrywers Christosentries was, maar dat Jesus self Teosentries was. Op grond van hierdie standpunt betwyfel hy nie Christus se godheid of die sentrale plek wat Jesus in Christene se godsdienstige lewe moet inneem nie. Hy waarsku egter teen Christomonisme waarin Christus gesien word as 'n soort kultiese figuur wat teenoor ander godsdienstige figure gestel word. Samartha (1987:76) sê dat Jesus van Nasaret vir Christene God se Christus is. Om egter te beweer dat die "Misterie" slegs in een persoon en op 'n spesifieke punt geopenbaar is, kom op liefdeloosheid neer. Daar moet eerder aanvaar word dat ander godsdienste hulle eie reaksies het op die "Misterie" en daarom ook hulle eie religieuse figure en openbaring sal hê.

Samartha (1982:101-102) stel dat sending 'n integrale deel is van die Christelike geloof. Daar moet egter volgens hom altyd onthou word dat ander gelowe ook húlle boodskap moet verkondig. Die woord sending moet daarom volgens Samartha laat vaar word en daar moet eerder gepraat word van "getuig". In hierdie getuienis gaan dit dan nie oor die voorafaanvaarding van Jesus Christus as Verlosser nie. Getuig gaan daaroor dat Christelike gemeenskappe die heerskappy van Christus moet erken deur hulle betrokkenheid in die stryd vir geregtigheid.

\subsection{Paul F. Knitter}

Knitter is ' $n$ teologiese professor aan die Xavier-universiteit in Cincinnati en staan 'n "unitive pluralism of religions" voor as antwoord op die huidige pluralistiese wêreld waarin die Christen leef (Knitter, 1985:5-20; vgl. ook Knitter, 1987:181). Hierdie "unitive" godsdienspluralisme moet volgens hom nie verwar word met 'n sinkretisme waarin net die gemeenskaplike kern van elke godsdiens behou word nie. Die genoemde godsdienspluralisme is ook nie imperalisties in die sin dat een godsdiens ander godsdienste suiwer en absorbeer nie. So 'n godsdienspluralisme is egter ook nie 'n "lui verdraagsaamheid" waarin elke godsdiens se geldigheid erken word en elkeen op sy eie weg van selftevredenheid voortbeweeg nie. Volgens Knitter impliseer "unitive pluralism" 'n eenheid waarin elke godsdiens, alhoewel dit 'n deel van sy individualisme (sy aparte ego) verloor tog sy "personality (its selfawareness through relationship)" sal intensiveer. Vir Knitter (1985:202) is God die "Deus semper major, the God ever beyond". Hoewel God hom deur middelaars bekend maak, kan geen geloofsgemeenskap ooit daarop aanspraak maak dat dit wat hulle van God via die middelaar te wete gekom het, die volle kennis van God is nie. God bly 'n "mystery ever more than what has been made known ...". 
Knitter (1985:200-201) verkies 'n teosentriese, nie-normatiewe herinterpretasie van die uniekheid van Christus. Volgens Knitter het die NuweTestamentiese kerk reeds van die begin af verskillende interpretasies aan Jesus en sy betekenis gemaak. Jesus self was volgens hom Teosentries in die boodskap wat Hy verkondig het, terwyl die vroeë kerk 'n Christosentriese boodskap verkondig het. Binne hierdie Christosentriese siening van die vroeë kerk was daar ook, as gevolg van mense se verskillende sosiale omstandighede, verskillende standpunte oor Jesus en sy boodskap - verskille wat volgens Knitter duidelik in die Nuwe Testament na vore kom. Knitter (1985:179) is oortuig dat daar in die interpretasies van Jesus 'n evolusie plaasgevind het. Hy sê ook dat beelde van Jesus in die Nuwe Testament nie alles bekend maak van wie hierdie man was en wat hy vir die Christen en die wêreld beteken nie. Die evolusionêre interpretasieproses in die Christologie wat in die Nuwe Testament gevind word, moet daarom vandag voortgesit word. Hierdie evolusionêre interpretasieproses kan tot stand kom op grond van dialoog met ander godsdienste waarin die Christen oop is vir nuwe beelde van Jesus.

Knitter (1985:185) gee ook aandag aan die Nuwe-Testamentiese uitsprake waarin die eksklusiwiteit van Jesus na vore kom, byvoorbeeld Johannes 1:14 en Handelinge 4:12. Hierdie uitsprake weerspieël volgens Knitter die entoesiasme van gelowiges en is nie bedoel om as dogmatiese definisies te dien nie. Die vleeswording van Jesus noem Knitter 'n ongeloofbare en 'n eksklusivistiese verstaan van Jesus wat vermy moet word. Hy sê dat die geloof in die vleeswording as mite gesien moet word. Dit is "a meaningful model, for expressing what Christians have experienced Jesus to be".

Volgens Knitter (1985:222-223) moet die tradisionele model vir sending nuut bedink word. Hy sê die primêre werk van die kerk behels nie die "salvation business" nie, maar die bevordering van die koninkryk van geregtigheid en liefde. Om hierdie koninkryk te bevorder, moet Christus verkondig word, want op grond van hierdie verkondiging sal alle mense van Christus weet. Dit is egter volgens Knitter ook belangrik dat alle mense van Boeddha, Mohammed en Krishna sal weet. Deur wedersyds te getuig word die koninkryk van geregtigheid en liefde bevorder, aangesien mense sodoende 'n beter begrip van God se teenwoordigheid en sy doel in hierdie wêreld verkry. Die doel van verkondiging is om Christene getrouer Christene te maak en mense in nie-Christelike godsdienste ook meer getrou in hulle onderskeie godsdienste te maak. 


\subsection{Samevatting}

Op grond van die standpunte van die voorafgaande skrywers kan die volgende samevatting van godsdienspluralisme gegee word:

- Alle vorme van godsdiens-eksklusivisme word binne die verskynsel van godsdienspluralisme as uiters negatief beoordeel.

- Godsdiens-inklusivisme, soos in punt 2 uiteengesit, is vir die voorstanders van godsdienspluralisme onaanvaarbaar, aangesien ander godsdienste binne die verskynsel van godsdiens-inklusivisme vanuit die Christelike perspektief beoordeel word.

- Volgens godsdienspluraliste is daar verskillende weë na God wat almal ewe geldig is. Dit is nie net die Christendom wat oor die waarheid beskik nie.

- Binne die verskynsel van godsdienspluralisme word die relatiewe en voorwaardelike aard van alle godsdienstige ervarings beklemtoon en word gewys op die belangrike rol van die konteks waarbinne geloofsgemeenskappe hulle standpunte formuleer.

- Vir godsdienspluraliste staan die onkenbaarheid van God sterk op die voorgrond. Om hierdie onkenbaarheid te be-teken word God byvoorbeeld die Real of die Ultimate Mystery genoem.

- Die betekenis van Jesus Christus word in die godsdienspluralisme drasties gereduseer. Binne die verskynsel van die godsdienspluralisme word geïmpliseer dat God Homself nie uniek, finaal en normatief in Jesus Christus geopenbaar het nie. Hoewel Jesus erken word as unieke openbaarder en verlosser, is Hy slegs een van baie sulke openbaarders en verlossers. Volgens die pluralisme moet in die teologie wegbeweeg word van Christosentriese denke en moet eerder Teosentries geredeneer word.

- Die verkondiging van die evangelie met die oog daarop om mense tot geloof in Jesus Christus te bring, word in die godsdienspluralisme verwerp. "Mutual witnessing" word voorgestaan waarin godsdienste deur dialoog by mekaar leer en geregtigheid op hierdie aarde bevorder word.

\section{M.A. Kruger en godsdiens-inklusivisme en -pluralisme}

Wanneer Kruger se standpunte oor mense in nie-Christelike godsdienste met die twee denkstrome godsdiens-inklusivisme en godsdienspluralisme vergelyk word, blyk die volgende: 


\subsection{God se voortgaande openbaring}

Kruger neem sterk standpunt in oor God se "voortgaande openbaring". Volgens Kruger (1993:54-58) blyk dit uit Romeine 1-4 dat daar drie soorte Godsopenbaring onderskei kan word. Hy sê dat Paulus vanaf Romeine 1:19 oor die eerste soort openbaring handel, naamlik God se openbaring in die skepping. Vanaf Romeine 2:1 handel Paulus oor die tweede soort openbaring, naamlik "die woorde van God" (vgl. 3:2). In Romeine 3:21 kondig Paulus 'n derde soort openbaring aan, die "klimaks van alle self-bekendmaking", te wete die "geregtigheid" van God. Hierdie geregtigheid verwys volgens Kruger na Christus. Kruger se standpunt oor nie-Christelike godsdienste is veral gegrond op sy siening van God se openbaring in die skepping: "God het nie, soos die deïste beweer, Hom teruggetrek en die aarde aan homself oorgelaat nie. Hy werk vandag nog en openbaar Homself vandag nog - daar is nie 'n afsluiting van die openbaring nie" (Kruger, 1993:67). Hy lei uit Romeine 1:20 en Romeine 10 af dat God se openbaring in die skepping, onderhouding en regering van alle dinge "genoegsaam is om iemand tot redding te lei" (Kruger, 1993:59-60; vgl. ook 1988:85-86). Omdat God Homself ook in die skepping genoegsaam openbaar om gered te word, is dit volgens Kruger (2000:23-24) moontlik dat daar in ander godsdienste mense kan wees wat ware gelowiges is. Sulke mense is mense wat nooit met die Skrifte gekonfronteer is nie en daarom nie 'n "clear view" het nie. Hoewel hierdie mense tot 'n nie-Christelike godsdiens behoort, neem hulle net in naam daaraan deel - net soos daar ook in Christelike kerke mense is wat net in naam Christene is.

Kruger kom in sy standpunt oor God se openbaring in die Skrif en oor die genoegsaamheid van God se voortgaande openbaring in 'n groot mate ooreen met skrywers soos Rahner, Küng, Pinnock en Sanders (vgl. pt. 2). Hy verskil egter baie duidelik van skrywers uit die pluralistiese denkrigting waarvolgens geen godsdiens daarop kan aanspraak maak dat dit die unieke, onfeilbare en vasstaande openbaring van God ontvang het nie.

\subsection{God se genade en liefde}

Kruger (1983:370) vra: "Is dit denkbaar dat God te min van homself sal bekend maak sodat die gevolg sal wees dat die mens God nie kan ken nie?" Dit is ook vir hom onaanvaarbaar dat "God in sy openbaring die res van die wêreld wat nie die Skrif gehad het nie, altyd sonder genade verby gegaan het". Die rede waarom Kruger oortuig is dat God Hom aan alle mense sal openbaar, word duidelik wanneer hy beklemtoon dat God Hom persoonlik en liefdevol aan die wêreld wat nie die Skrif het nie, openbaar (Kruger, 1993:63) en wanneer hy op die oorweldigende plek 
van God se genade in die Skrif (Kruger, 1993:67) wys. Kruger (2000:2223) verwys ook na God se "seeking love for his highest creature". In hierdie beklemtoning van God se liefde en genade stem Kruger in 'n groot mate ooreen met die motivering wat skrywers uit die godsdiensinklusivistiese denkrigting aanbied waarom 'n godsdiens-eksklusivistiese standpunt onaanvaarbaar is. Vanweë God se groot genade en liefde kan Kruger en ander godsdiens-inklusiviste nie aanvaar dat God slegs mense wat met die besondere openbaring van die Skrif te doen gehad het, sou red nie.

\subsection{Die verlossing van mense wat nie die inhoud van die Skrif gehoor het nie}

Kruger (2000:16) wys op Bavinck se standpunt dat God se openbaring in die skepping, regering en onderhouding van die wêreld nie die mens tot kennis van Jesus Christus kan bring nie en daarom onvoldoende is om mense tot redding te lei. In Kruger se reaksie op Bavinck beklemtoon hy dat kennis as 'n element van geloof nie oorskat moet word nie, en dat vertroue nie onderskat moet word nie. Hy vra: "How much knowledge is necessary to bring one to a firm trust in God? Must there be a knowledge of the Trinity? A knowledge of what Christ suffered and did?" Hy wys ook daarop dat Ou-Testamentiese gelowiges wel meer kennis van Jesus gehad het as die mense in die heidense volke, maar minder as wat in die Nuwe Testament aan ons geopenbaar is. Kruger (2000:23) aanvaar dat mense gered word wat net die openbaring van God in die skepping, onderhouding en regering van die wêreld ontvang het, "[when they] come to the true knowledge of themselves and as poor in spirit throw themselves in full trust upon God who speaks to them and for their benefit in this language ...." Dit blyk dat Kruger nie hierdie redding deur God as 'n redding buite die verlossingswerk van Christus beskou nie. Hy (Kruger, 2000:16) sê dat waar 'n "obedient act of submission to the God who reveals himself in the creation, preservation and government of the universe" is, is daar ook onderwerping aan die drie-enige God en dus ook aan Christus. Kruger maak dit egter duidelik dat nie alle mense wat nie met die inhoud van die Skrif gekonfronteer word nie, gered sal word nie. Kruger (1983:379) wys op Romeine 1:18-32 en sê dat mense in ander godsdienste wat nie tot vertroue in die ware God kom nie, "moedswillige onderdrukkers van die waarheid" is. Kruger distansieer hom in hierdie verband uitdruklik van Rahner se gedagte van anonieme Christene in ander godsdienste. Hy sê Rahner is in sy filosofie optimisties ten opsigte van die heidense godsdienste. Volgens hom aanvaar Rahner verkeerdelik dat mense in hierdie godsdienste reeds implisiete genade ontvang en 'n implisiete geloof het. 
Kruger toon in sy standpunt oor die redding van mense aan wie die inhoud van die Skrif nie verkondig is nie, duidelike ooreenkomste met die godsdiens-inklusivisme. Soos die inklusivisme aanvaar hy dat Christus se versoeningswerk ontologies noodsaaklik is om gered te word, maar nie epistomologies nie. Anders as sommige van die skrywers uit die inklusivistiese geledere (vgl. punt 2) beklemtoon Kruger egter dat mense in ander godsdienste eers tot vertroue moet kom in die God wat Hom in die skepping, onderhouding en regering van die wêreld openbaar, alvorens hulle gered is. Dit is duidelik dat Kruger Christus as unieke, finale en normatiewe Verlosser beskou en dat daar buite Hom geen verlosser is nie. Hierin verskil Kruger radikaal van skrywers uit die godsdienspluralistiese geledere.

\subsection{Die werk van die Heilige Gees}

In Kruger se standpunt oor mense in ander godsdienste staan die werk van die Heilige Gees sentraal (Kruger, 2000:24; vgl. ook 1988:93-95). Volgens Kruger bestaan daar 'n "dangerous view" binne die Gereformeerde teologie dat die Heilige Gees mense alleen deur die Skrif wederbaar. Hy erken dat die weg wat die Heilige Gees deur die Skrif volg, die voortreflikste weg is. Dit is egter nie die enigste weg nie. Kruger (1983:378-379) aanvaar dat die Gees mense ook deur God se voortgaande openbaring in die skepping, onderhouding en regering van die wêreld kan wederbaar. Kruger (2000:20) wys op Romeine 1 en sê dat mense wat God se openbaring in die skepping, onderhouding en regering van die wêreld verwerp, in werklikheid teen die Heilige Gees werk. Kruger (1983:378) beklemtoon egter dat geen mens self in staat is om God se openbaring te aanvaar nie. Hy sê dat "'n onwedergeborene dood is in sonde, dat hy onmagtig is om te lewe en dat slegs deur die wedergeboorte as daad van die Heilige Gees, daar lewe kan wees".

By sowel die godsdiens-inklusivistiese as die godsdienspluralistiese skrywers word dikwels veel gemaak van die werk van die Heilige Gees (vgl. punte 2 en 3.3). Kruger stem in sy standpunt oor die werk van die Heilige Gees met inklusivistiese skrywers soos Pinnock en Sanders (vgl. punte 3) saam wanneer hy sê dat die Gees nie alleen deur God se selfopenbaring in die Skrif werk nie, maar ook deur die voortgaande openbaring in die skepping. Kruger verskil grootliks van godsdienspluralistiese skrywers aangaande die werk van die Heilige Gees. Daar kan afgelei word dat Kruger verskil met 'n pluralistiese skrywer soos Samartha (vgl. punt 3.3) wat glo dat die Heilige Gees los van Christus, versoeningswerk in ander godsdienste bewerkstellig. 


\subsection{Die kenbaarheid van God}

Dit is duidelik dat Kruger glo dat God kenbaar is. God openbaar Hom in drie "openbaringsvorme" soos in punt 4.1 hier bo gemeld is, en hierdie openbaring "lei tot Godskennis" (Kruger, 1993:67). Om die Godsopenbaring te verstaan, speel die Heilige Gees 'n sentrale rol. "Die Heilige Gees is die doctor ecclesiae by sowel die interpretasie van die Skrif as van God se voortgaande openbaring" (Kruger, 1993:67).

Terwyl daar duidelike ooreenkomste is tussen Kruger en die godsdiensinklusiviste oor die kenbaarheid van God (vgl. punt 2), is daar baie uitdruklike verskille oor hierdie saak tussen hom en die godsdienspluraliste. Teenoor Hick, Panikkar, Samartha en Knitter (vgl. punt 3) wat sê dat God nie werklik geken kan word nie, stel Kruger duidelik dat die mens tot ware Godskennis kan kom (vgl. punt 4.1).

\subsection{Die noodsaak van sending}

Die feit dat "mense sonder die verkondigde evangelie ook salig" kan word, maak volgens Kruger (1983:378-379) nie die verkondiging van die evangelie onnodig nie. Hy wys daarop dat Paulus wat leer dat mense wat deur God se voortgaande openbaring tot geloof kan kom, ook die groot sendeling is. Hy noem ook dat daar in nie-Christelike godsdienste mense is wat, ondanks die feit dat God Homself voldoende in die voortgaande openbaring bekendmaak, die waarheid onderdruk en afgodery beoefen. Aan hierdie afgodsdienaars moet die evangelie, wat kragtiger is as die voortgaande openbaring in die skepping, verkondig word.

Wanneer Kruger se standpunt oor sending met die standpunte van skrywers soos Rahner, Pinnock en Sanders vergelyk word, is dit duidelik dat hy grootliks met hulle saamstem oor die noodsaak van en die motivering vir sending. Hy verskil egter duidelik van die godsdienspluralistiese standpunte van Hick, Panikkar, Samartha en Knitter dat die verkondiging van die evangelie om mense tot geloof in Jesus Christus te bring, laat vaar moet word.

\section{Gevolgtrekkings}

\subsection{Kruger en godsdiens-inklusivisme}

Kruger se standpunte toon duidelik ooreenkomste met 'n veranderde denkrigting oor nie-Christelike godsdienste. Sy siening verskil van die godsdiens-eksklusiewe standpunt dat alleen mense wat Christus ken en in Hom persoonlik glo, gered is. Kruger neem 'n godsdiens-inklusivistiese standpunt in wat onder andere die volgende behels: 
- God openbaar Homself genoegsaam in die skepping, onderhouding en regering van die wêreld "om mense tot redding te lei". Daar kan dus mense in nie-Christelike godsdienste wees wat net in naam daaraan behoort maar wat, hoewel hulle nie 'n helder perspektief het nie, tog tot ware Godskennis gekom het en ware kinders van God is.

- Vanweë God se groot genade en soekende liefde is dit onaanvaarbaar dat God by mense wat nie die Skrif het nie, in sy openbaring sou verbygaan.

- Die kenniselement van 'n ware geloof moet nie oorskat word nie. Mense wat nie die Skrif het nie en God alleen uit die skepping leer ken het, kan ware gelowiges wees as hulle tot ware kennis van hulleself gekom het en ook as hulle, vanuit die besef dat hulle mense is wat arm van gees is, vertrou op dié God wat Hom aan hulle in die skepping geopenbaar het. Al sou hierdie mense Christus nie so duidelik ken soos Hy in die Skrif geopenbaar word nie, is hulle redding nie buite Christus nie. Die God wat Hom in die skepping openbaar, is immers die drie-enige God. Wie in Hom glo, glo ook in Christus.

- Die Gees wederbaar mense nie alleen deur die Skrif nie. Hoewel dit die voortreflikste weg is wat die Gees volg, kan die Gees mense ook deur God se voortgaande openbaring in die skepping, onderhouding en regering van die wêreld wederbaar. Mense wat deur God se openbaring in sy skepping, regering en onderhouding van die wêreld tot geloof kom, doen dit nie op grond van eie prestasie nie. Dit is alleen deur die wederbarende werk van die Heilige Gees dat iemand tot geloof kom.

- Hoewel "mense sonder die verkondigde evangelie ook salig" kan word, neem dit nie die noodsaaklikheid vir sending weg nie. Daar is nog altyd mense wat, ondanks die feit dat God Homself voldoende in die skepping openbaar, die waarheid onderdruk en afgodery beoefen. Aan hierdie afgodsdienaars moet die Skrif, waardeur God Homself kragtiger as in die skepping openbaar, verkondig word.

\subsection{Kruger en godsdienspluralisme}

Hoewel Kruger wegbeweeg van die godsdiens-eksklusiewe denke en 'n meer inklusiewe standpunt inneem, kom sy oortuigings nie ooreen met die godsdienspluralistiese denke nie. Hy verskil onder andere van die pluralisme in die volgende opsigte:

- Kruger se standpunt oor die openbaring van God staan in skrille kontras met die pluralistiese denkrigting waarvolgens geen godsdiens daarop kan aanspraak maak dat dit die onfeilbare en vasstaande openbaring van God ontvang het nie. 
- Anders as godsdienspluralistiese skrywers aanvaar Kruger dat Christus die unieke, finale en normatiewe Verlosser is en dat daar buite Hom geen verlosser is nie.

- Daar is 'n verskil tussen Kruger en godsdienspluralistiese skrywers aangaande die werk van die Heilige Gees. Anders as byvoorbeeld 'n skrywer soos Samartha (vgl. punt 3), is dit duidelik dat Kruger nie glo dat die Heilige Gees los van Christus se versoeningswerk in ander godsdienste werk nie.

- Teenoor die godsdienspluralisme wat beweer dat God nie werklik geken kan word nie, stel Kruger dat die mens tot ware Godskennis kan kom.

- Kruger stem nie saam met die godsdienspluralisme dat die evangelie nie aan mense in nie-Christelike godsdienste verkondig moet word met die doel om hulle tot geloof in Jesus Christus te lei nie. Mense in ander godsdienste wat die waarheid wat God in sy voortgaande openbaring bekendgemaak het, onderdruk, is afgodsdienaars. Aan hulle moet die evangelie verkondig word sodat hulle kan glo en gered word. Hy verskil ook met die pluralisme dat verskillende godsdienste in 'n gesindheid van dialoog teenoor mekaar moet getuig. Vir Kruger is dit wat God in Christus geopenbaar het, die ware Godsopenbaring en daar kan nie deur dialoog met ander godsdienste tot suiwerder openbaring gekom word nie.

\section{Bibliografie}

AMALADOSS, M. 1986. Dialogue and mission: conflict or convergence? International Review of Mission, 75(297):222-241, Jan.

ANDERSON, G.H. 1998. Christian mission and religious pluralism: a selected bibliography of sixty-seven books in English, 1991-1998. International Bulletin, 22(1):159-160, Jan.

ATHYAL, J.M. 2002. Relevant patterns of Christian witness in pluralistic societies: an Indian perspective. International Review of Mission, 91(361):199-209, April.

$\mathrm{BOSCH}$, D.J. 1979. Heil vir die wêreld. Die Christelike sending in teologiese perspektief. Pretoria : N.G. Kerkboekhandel.

BOSCH, D.J. 1991. Transforming mission: Paradigm shifts in the theology of mission. New York : Orbis.

CARSON, D.A. 1996. The gagging of God. Christianity confronts pluralism. Michigan : Zondervan.

D'COSTA, G. 1991. The new missionary: John Hick and religious plurality. International Bulletin, 15(1):66-69, Jan.

DE KLERK, W.J. 1998. Die vreemde God en sy mense. Pretoria : Human \& Rousseau.

ERICKSON, M.J. 1996. How shall they be saved? The destiny of those who do not hear of Jesus. Grand Rapids : Baker. 
GAYBBA, B. 1994. Christology and religious pluralism. The search for a route between inclusivism and pluralism. Journal of Theology for Southern Africa, 87:3-10.

GILLIS, C. 1996. Evangelical inclusivism: progress or betrayal? The Evangelical Quarterley, 68(1):139-150, Jan.

HICK, J. 1973. God and the universe of faiths. London : Macmillan.

HICK, J. 1974. The outcome: dialogue into truth. (In Hick, J., ed. Truth and dialogue. The relationship between world religions. London : Sheldon. p. 140-150.)

HICK, J. 1981. Whatever path men choose is mine. (In Hick, J., Hebblethwaite, B., eds. Christanity and other religions. Philadelphia : Fortress. p. 171-190.)

HICK, J. 1987. The non-absoluteness of Christianity. (In Hick, J., Knitter, P.F., eds. The myth of Christian uniqueness. Toward a pluralistic theology of religions. Maryknoll : Orbis. p. 16-36.)

HICK, J. 1995. The rainbow of faiths. Critical dialogues on religious pluralism. London : SCM.

KAUUOVA, W. 1997. Religious pluralism as a challenge to the church in Southern Africa. Potchefstroom : Institute for Reformational Studies.

KETSHABILE, K.F. 1997. An African contribution to the Christian debate on religious pluralism. Pretoria : UNISA. (M.A.-verhandeling.)

KNITTER, P.F. 1985. No other name? A critical survey of Christian attitudes toward the world religions. London : SCM.

KNITTER, P.F. 1987. Toward a liberation theology of religions. (In Hick, J., Knitter, P.F., eds. The myth of Christian uniqueness. Toward a pluralistic theology of religions. Maryknoll : Orbis. p. 178-202.)

KRUGER, M.A. 1983. Openbaring, geloof en geregtigheid. 'n Eksegetiese ondersoek van Romeine 1-4. Pretoria : Universiteit van Pretoria. (Doctor Divinitasproefskrif.)

KRUGER, M.A. 1988. Naby jou is die Woord! - Romeine 10:8. (In Coetzee, J.C., red. Koninkryk, Gees en Woord. Pretoria : NG Kerkboekhandel. p. 81-97.)

KRUGER, M.A. 1993. Openbaring as principium theologiae. In die Skriflig, 27(1):5368, Maart.

KRUGER, M.A. 2000. The Kingdom of God and those who have not heard the contents of Scripture. Ongepubliseerde voordrag gehou by die Gereformeerde Teologiese Kongres te Potchefstroom, Augustus 2000.

KÜNG, H. 1967. The world religions in God's plan of salvation. (In Neuner J., ed. Christian revelation and world religions. London: Burnes \& Oates. p. 16-113.)

KÜNG, H. 1976. On being a Christian. New York : Doubleday.

PANIKKAR, R. 1981. The unknown Christ of Hinduism. Towards an ecumenical Christophany. Maryknoll : Orbis.

PANIKKAR, R. 1987. The Jordan, the Tiber, and the Ganges. Three kairological moments of Christic self-consciousness. (In Hick, J., Knitter, P.F., eds. The myth of Christian uniqueness. Toward a pluralistic theology of religions. Maryknoll : Orbis. p. 89-116.)

PANIKKAR, R. 1999. The intra-religious dialogue. New York : Paulist Press.

PINNOCK, C.H. 1992. A wideness in God's mercy. The finality of Jesus Christ in a world of religions. Grand Rapids : Zondervan.

PINNOCK, C.H. 1993. Acts 4:12 - No other name under heaven. (In Crockett, W.F., Sigountos, J.G., eds. Through no fault of their own? The fate of those who have never heard. Grand Rapids : Baker. p. 107-116.) 
RAHNER, K. 1981. Christianity and the non-Christian religions. (In Hick, J., Hebblethwaite, B., eds. Christianity and other religions. Philadelphia : Fortress. p. 52-97.)

RICHARD, R.P. 1994. Soteriological inclusivism and dispensationalism. Bibliotheca Sacra, 151(601):85-108, Jan.-March.

SAMARTHA, S.J. 1982. Courage for dialogue. Ecumenical issues in inter-religious relationships. Maryknoll : Orbis.

SAMARTHA, S.J. 1987. The cross and the rainbow. Christ in a multireligious culture. (In Hick, J., Knitter, P.F., eds. The myth of Christian uniqueness. Toward a pluralistic theology of religions. Maryknoll : Orbis. p. 69-88.)

SANDERS, J. 1992. No other name. Can only Christians be saved? Grand Rapids : Eerdmans.

SANDERS, J. 1995. Inclusivism. (In Sanders, J., ed. What about those who have never heard? Three views on the destiny of the unevangelized. Illinois : InterVarsity Press. p. 21-55.)

SCHROEDER, E.H. 1999. Pluralism's question to Christian missions: Why Jesus at all? Currents in Theology and Mission, 26(1):164-170, Febr.

SHENK, C.E. 1997. Who do you say that I am? Christians encounter other religions. Pennsylvania : Herald.

STETSON, B. 1994. Pluralism and particularity in religious belief. London : Praeger.

TURNER, H.W. 1991. Historical support for pluralism? The "Copernicum revolution" re-visited. Mission Studies, 8(1):77-92.

TUTU, D.M. 1994. Let us celebrate our diversity. (In Lubbe, G., ed. A decade of interfaith dialogue. Pretoria : UNISA. p. 124-130.)

Vatican II: Declaration on the relation of the church to non-Christian religions. 1981. (In Hick J. \& Hebblethwaite, B., eds. Christianity and other religions. Philadelphia : Fortress. p. 80-86.)

WRIGHT, D. 1992. The watershed of Vatican II. Catholic approaches to religous pluralism. (In Clark, A.D., Winter, B.W., eds. One God, one Lord. Christianity in a world of religious pluralism. Michigan : Baker. p. 207-226.)

YONG, A. 1999. Whither theological inclusivism? The development and critique of an evangelical theology of religions. The Evangelical Quarterley, 71(4):327-348, Oct.

\section{Kernbegrippe:}

godsdiens-eksklusivisme

godsdiens-inklusivisme

godsdienspluralisme

Kruger, M.A.

\section{Key concepts:}

religious exclusivism

religious inclusivism

religious pluralism

Kruger, M.A. 
